Iryna BEI, Postgraduate Student in the 3rd year of studies at the Department of Theory and Methods of Preschool and Special Education of Vasyl Stefanyk Precarpathian National University

\title{
RETROSPECTIVE ANALYSIS OF USING PROJECT-BASED LEARNING IN EDUCATIONAL INSTITUTIONS OF THE USA
}

\author{
Ірина БЕЙ, аспірант третього року навчання кафедри теорії та \\ методики дошкільної і спечіальної освіти ДВНЗ "Прикарпатський \\ національний університет імені Василя Стефаника"
}

\section{РЕТРОСПЕКТИВНИЙ АНАЛІЗ ВИКОРИСТАННЯ ПРОЕКТНОГО НАВЧАННЯ В ЗАКЛАДАХ ОСВІТИ США}

The article deals with analysis of historical origins, formation and development of the project method in the USA pedagogy. There have been defined main directions of implementing project learning ideas in American educational institutions in various historical periods. It also presents basic states of pragmatic pedagogy which were introduced by such representatives of American scientific school as: John Dewey, William H. Kilpatrick and Ellsworth Collings.

Key words: American scientific school, historical analysis, project method, pragmatic pedagogy, educational institutions of the USA.

Анотація. У статті проаналізовано історію зародження, становлення та розвитку методу проектів у педагогіці США; визначено основні напрями реалізації ідей проектного навчання в американських закладах освіти в різні історичні періоди; представлено основні положення педагогіки прагматизму, які впроваджували такі представники американської наукової школи, як: Дж. Дьюї, В. Кілпатрік та Е. Коллінгс.

Ключові слова: американська наукова школа, історичний аналіз, метод проектів, педагогіка прагматизму, заклади освіти США.

Problem statement. Ukraine's integration into the European and world community, accession of the native higher-education system to Bologna Declaration, focus on the AllEuropean recommendations concerning language learning bring specific requirements for the professional training of future foreign languages teachers.

In this connection the problem of introducing innovative technologies into the learning process of higher educational institutions is taking on special significance. A considerable place in the context of this issue occupies the project-based learning.

Its topicality is due to the fact that it is aimed at realization of a special model of the personality of a professional teacher, who is able to successfully implement a competencybased approach in educational institutions. Such a teacher must realize that nowadays is of great importance to create a person "capable of taking appropriate decisions, thinking critically, resolving problems creatively and tending to self-realization - that is a communicative personality" [2].

Accordingly, the problem of implementing the project-based learning on the faculties of foreign languages in higher pedagogical institutions we examine in foreign pedagogical researches. This is important because the project method, as an educational technology, appeared and is actively employed just in foreign pedagogy.

Requires a particular analysis the study of American scientific school about introducing project learning ideas since the project method at the beginning of the 20th century was considered as a specific American educational strategy and was admitted like a progressive phenomenon by the world pedagogical community.

The aim of the article is to provide a retrospective analysis of using the project-based learning in educational institutions of the USA, to present the ways of employing American experience in Ukrainian educational institutions.

Recent research and publications analysis. The research of psychopedagogical materials on the given problem proved that different angles of the origins, formation and development of the project method in the USA pedagogy had been already observed by scientists in detail.

Their scientific groundworks are devoted to the analysis of historical and theoretical aspects concerning the actual problem. The authors of these researches are: M. Chepil, I. Dychkivska, K. Dmytrenko, O. Ohiienko, O. Penkovskykh, L. Rohozina, V. Sternberh and others. They analyzed the process of forming the "project method" within historical perspective, defined main stages of introducing the mentioned phenomenon into educational systems of diverse foreign institutions, outlined strengths and weaknesses of the project-based learning in various historical periods.

However, it should be noted that these studies have mainly an abrupt character and highlight not fully the progressive tendencies of developing the project-based learning in foreign pedagogy.

Statement of basic materials. The project method was based on the American experience of pedagogy of pragmatism that started developing in the USA in the latter half of the 19th and in the early 20 th century. The leading representatives of the given direction are: John Dewey (1859-1952) 
and William Heard Kilpatrick (18711965).

John Dewey was an American psychologist, philosopher, educator and social critic. He is reputed a prominent representative of the progressive education in the USA pedagogy for basing the idea of pragmatic and democratic approaches in training pupils.

The scientist represented basic states of the conception of pedagogic pragmatism and claimed that human abilities are formed by nature while school provides conditions for its realization. The knowledge should be directed to enable a person to adapt to the environment and then use this information in practice.

Of particular importance for our scientific work are John Dewey's conclusions on the system analysis of project activity, examined by L. Rohozina.

The researcher states that these pedagogical ideas are relevant for modern education and for the higher school as well. On the basis of generalization of scientific developments on the issue, L. Rohozina singles out such theses of the project-based learning defined by American pedagogue:

1. Accumulating personal experience by pupils ranks above their acquiring of classified scientific knowledge.

This pedagogical statement by $\mathrm{J}$. Dewey, according to L. Rohozina, can be realized in the higher school in the following way: it is necessary to place greater focus on the connection between theory and practice within academic subjects, to emphasize vocationally-oriented themes. It is needed to give preference to active and on-line teaching methods, which stimulate forming such future specialist's essential qualities as: communication and teamwork abilities, sociability, criticality, thinking efficiency, training skills and others [6].

2. At the heart of teaching and educational process should be interests of students.

We consider this thesis to be important, since subject-to-subject education forms subjectivity as a personal trait of both students and lecturers. It improves students' training motivation, their responsibility for educational results and also generates a higher return from teaching under conditions of competitive learning environment.

3. Teaching should be oriented towards the future activity in society.

In our opinion the statement is actual in modern educational environment of the higher school. M. Fitsula affirms that pedagogical system is confronted with a problem of improving work of teachers universities concerning training future specialists with a high degree of proficiency, creative activity, who would be responsible for own educational outcomes and training for the future professional activity [3].

4. Using method of learning projects will contribute to the efficiency of training.

John Dewey and such his followers as William H. Kilpatrick and Ellsworth Collings deserve credit for developing and basing didactic principles of the method of learning projects. However, significantly is that J. Dewey was critical about domination of the project method in the classroom learning. The pedagogue believed that there was no point in organizing whole education on the basis of the given technology as he found it short-time, changeable and trivial which appeared to be incomplete for the meaningful education.

One of major deficiencies in the modern culture, according to John Dewey, is an availability of dualisms, in particular: theory and practice, knowledge and experience, thinking and feelings, physical and moral along with the dualism of object of science and object of morality. The science, in the researcher's opinion, must include human values and relations, but the experience is an "experimental intelligence" capable of self-correcting [1].

Much effort was applied to create a democratic society, as its progress is impossible without providing appropriate conditions for the development of young generation. John Dewey noted: "Democratic thinking is not a naturally given. It appears and develops by itself and this is possible only in democratic institutions, where difficulties arise as well. At the core of democracy are skills and attainments that require a growth without which they cannot temperate the natural needs" $[1, p$. 152].

The theory of project method provides introducing such educational system that will help pupils to acquire new knowledge in the process of planning and accomplishing gradually more complex practical tasks, that's to say - the projects. The positive sides of this method are: developing students' initiative, training skills for a planned work, ability to weigh the circumstances and take into account all difficulties, upbringing a persistence in achieving a goal, self-dependence organization.

William Heard Kilpatrick, the student and successor of John Dewey, made a great contribution to the development of the project-based learning.

The scientist was a follower of the pragmatic pedagogy and devised a pedagogical system of "experimentalism". It was supported by pragmatic philosophy and behavior psychology. William Kilpatrick believed that traditional school relied on the transfer of a ready-made knowledge to pupils and didn't have connection with the real life questions and children's vital requirements. He denied the necessity for school curriculum, classand-lesson system, emphasized the importance of teacher's positive influence on the child [4].

American pedagogue rejected the idea of traditional school and suggested organizing the educational process as a child's activity in social environment. This, he believed, would allow to enrich pupil's personal experience. The leading position in teaching the researcher gave to the project activity.

In his scientific work titled "Project Method" he has offered the first classification of projects characterizing the project method as a method of planning reasonable activity in connection with solving a certain learning problem in the real life situation.

William Kilpatrick presented a fourcomponent classification of school projects with the following educational goals: to put some idea or plan into practice, for instance to make up a sort of product; to find enjoyment in a particular esthetic experience as reading or listening to an interesting narration, admiring a picture and so on; to accomplish more difficult task; to obtain some new information etc.

It was he who considered the project as any activity with a high degree of pupils' self-dependence united at one point with a common interest.

The analysis of scientific studies on the problem showed that further 
generalization of working experience about the project method had been developed in the groundworks of a famous American scientist Ellsworth Collings.

He suggested introducing the project method into the learning process along with pointing out that this technology should be based on such interrelated ideas:

the school for the correct performing of its functions should let the pupils choose a kind of occupation they want;

the real education is never unilateral or separated;

firstly is picked up a type of project and only than the school subjects that are needed for its realization;

the program is a complex of organized experiments that are interrelated since everything studied in one range of experiments should become a basis for the next set of experiments [5].

This conception was accepted approvingly by the world scientific community.

Conclusions. On the basis of studing original American and native scientific reseches on the issue we have displayed coherent picture representing formation and development of the notion of "project method", its pedagogical interpretation in diverse cultural contexts. This let us identify the causes of highs and lows of popularity of the given method in various historical periods.

So, the retrospective analysis of the project activity in the USA pedagogy led to the following conclusions:

- the American pedagogues that developed the project method aimed at overcoming the distance between school and life, theory and practice therefore implementation of this method was the subject of pedagogic reform in the country;

- despite the differences in defining main characteristics of the projectbased learning, the scientists were of the same mind that the project method was a universal and could be used in teaching different disciplines at all levels of training. In the modern pedagogy it can be employed both in preschool institutions and in higher school.

Based on a comparative study of the materials concerning the actual problem, we have determined resembling and differential features of the project method in native and American pedagogy and proposed possible ways of its introduction into the learning process of Ukrainian educational institutions. This, in our opinion, will provide activating future foreign languages teachers' training in higher educational institutions.

\section{REFERENCES}

1. Dewey J. Democracy and Education. New York : The Free Press, 1966. P. 152-153.

2. Dmytrenko K.A. Zvychaini formy roboty - novyi pidkhid: rozvyvaiemo kliuchovi kompetentnosti: metod. posibnyk. Kharkiv: VH "Osnova", 2018. 119 s.

3. Fitsula M. M. Pedahohika vyshchoi shkoly: navch. posib. 2-he vyd., dop. Kyiv : Akademvydav, 2010. $456 \mathrm{~s}$.

4. Kilpatrick, W. H. (1918, September). The project method. Teachers College Record, 19, 319-335.

5. Kollings E. Opyt raboty amerikanskoy shkoly po metodu proyektov [per. s angl. S. Tyurbert] / pod red. A. U. Zelenko. predisl. U. Kilpatrika. Moskva : Novaya Moskva. 1926. $289 \mathrm{~s}$.

6. Rohozina L. A. Pedahohichni idei D. Diui u svitli suchasnykh osvitnikh tendentsii : Materialy XLVI naukovotekhnichnoi konferentsii pidrozdiliv
VNTU, Vinnytsia, 22-24 bereznia 2017 r. Elektron. tekst. dani. 2017. URL : https://conferences.vntu.edu.ua/ index.php/all-hum/all-hum-2017/paper/ view/2273.

7. Sternberg. V. N.Teoriya i praktika "metoda proyektov" v pedagogike XX veka : avtoreferat k diss. Ryazan. 2003. URL : Rezhim dostupa:http://naukapedagogika.com/pedagogika-13-00-01.

\section{ЛІТЕРАТУРА}

1. Дмитренко К. А. Звичайні форми роботи - новий підхід: розвиваємо ключові компетентності: метод. посібник. Харків : ВГ "Основа", 2018. $119 \mathrm{c}$.

2. Коллингс Е. Опыт работы американской школы по методу проектов [пер. с англ. С. Тюрберт]; под ред. А. У. Зеленко, предисл. У. Кильпатрика. Москва : Новая Москва, 1926. $289 \mathrm{c}$.

3. Рогозіна Л. А. Педагогічні ідеї Д. Дьюї у світлі сучасних освітніх тенденцій : Матеріали XLVI науково-технічної конференції підрозділів ВНТУ. Вінниця, 22-24 березня 2017. URL : https://conferences.vntu.edu.ua/ index.php/all-hum/all-hum-2017/paper/ view/2273.

4. Стернберг В. Н. Теория и практика "метода проектов" в педагогике XX века : автореф. дис. Рязань, 2003. URL :http://nauka-pedagogika.com/ pedagogika-13-00-018.

5. Фіцула М. М. Педагогіка вищої школи: навч. посіб. 2-ге вид., доп. Київ: Академвидав, 2010. 456 с.

6. Dewey J. Democracy and Education. New York : The Free Press, 1966. P. 152-153.

7. Kilpatrick, W. H. (1918, September). The project method. Teachers College Record, 19, 319-335.

Стаття надійшла 18.03.2019 p. 